\title{
PELATIHAN DAN PENDAMPINGAN PENELITIAN TINDAKAN KELAS BAGI GURU-GURU SD DI KEBENDESAAN MENGESTA
}

\author{
I Made Mariawan 1,*, Ni Ketut Rapi ${ }^{2}$, Putu Yasa ${ }^{3}$ \\ 1 Jurusan Pendidikan Fisika. Universitas Pendidikan Ganesha, Indonesia \\ 2 Jurusan Pendidikan Fisika. Universitas Pendidikan Ganesha, Indonesia \\ 3 Jurusan Pendidikan Fisika. Universitas Pendidikan Ganesha, Indonesia
}

\begin{abstract}
Abstrak
Tujuan dari kegiatan Pengabdian pada Masyarakat (P2M) ini adalah meningkatkan pengetahuan dan keterampilan para guru dalam menyusun dan mengimplementasikan penelitian tindakan kelas (PTK) dalam kegiatan pembelajaran. Kegiatan P2M ini melibatkan 32 orang guru SD dan Kepala sekolah di Kebendesaan Mengesta dalam bentuk pelatihan dan pendampingan. Dari 32 orang guru yang ikut pelatihan, dipilih 6 orang yang didampingi dalam mengimplementasikan PTK di sekolah masing-masing. Pelaksanaan kegiatannya, sebagai berikut: (1) Melaksanakan pelatihan tentang penyusunan proposal PTK selama satu hari. (2) Membimbing guru dalam mengimplementasikan PTK dalam kegiatan pembelajaran selama dua bulan. (3) Melakukan penilaian terhadap kemampuan guru dalam menyusun proposal PTK dan mengimplementasikan PTK dalam kelas. Hasil yang diperoleh dari seluruh kegiatan P2M ini adalah rata-rata kemampuan mengajar guru dalam mengimplementasikan PTK, berkualitas " sangat baik". RPP yang disusun guru, berkualitas "baik". Rata-rata respon siswa "sangat baik" terhadap pelaksanaan pembelajaran yang dilaksanakan guru.

Keywords:

penelitian tindakan

kelas, pelatihan PTK,

pendampingan PTK
\end{abstract}

\section{Pendahuluan}

Undang-undang tentang Guru dan Dosen menyatakan bahwa guru adalah pendidik profesional dengan tugas utama mendidik, mengajar, membimbing, mengarahkan, melatih, menilai, dan mengevaluasi peserta didik (UU No. 14 tahun 2005). Dengan tugas seperti ini, seorang guru sudah sepatutnya selalu berupaya meningkatkan profesionalisme diri agar dapat melaksanakan tugas dengan sebaik-baiknya. Kualitas mutu pendidikan tidak terlepas dari kualitas guru sebagai ujung tombak pelaksanaan pendidikan.

Kualitas mutu pendidikan Indonesia sudah sangat jauh tertinggal dibandingkan dengan negara lain. Hal ini terlihat dari kompetensi pelajar Indonesia masih di bawah pelajar lain di Asia, seperti Jepang, Thailand, Singapura, dan Malaysia. Hanya 5 persen pelajar Indonesia memiliki kompetensi berpikir analitis. Kompetensi sebagian besar pelajar pada tingkat mengetahui. Data itu mengacu laporan McKinsey Global Institute "Indonesia Today" dan sejumlah data rangkuman Kementerian Pendidikan dan Kebudayaan (KOMPAS, 3 Desember 2013).

Salah satu upaya yang dapat dilakukan guru dalam upaya meningkatkan profesionalismenya adalah dengan meningkatkan kualitas pelaksanaan pembelajaran. Guru dapat melakukan inovasi-inovasi pembelajaran dengan mengikuti perkembangan kurikulum dan perkembangan IPTEKS. Hal ini dapat dilakukan guru dengan mengembangkan budaya membaca, meneliti, dan menulis terkait dengan upayaupaya inovasi dalam pembelajaran yang dapat dan yang telah dilakukannya.

Sebagai wujud penghargaan pemerintah terhadap upaya peningkatan kualitas diri seorang guru, mereka diberikan kesempatan untuk mendapatkan peluang kenaikan pangkat. Hal ini tentu saja memberikan dampak tidak hanya bagi peningkatan jenjang karir, juga peningkatan kesejahteraan guru, karena akan diikuti oleh bertambahnya penghasilan mereka. Bagi guru PNS yang akan mengusulkan kenaikan pangkatnya, pemerintah telah menetapkan peraturan yaitu harus memenuhi beberapa kriteria seperti angka kredit point yang harus didapat dalam pengembangan diri dan karya tulis (Permen PANRB No. 16, 2009). Lebih lanjut dijelaskan, dalam setiap jenjang kenaikan pangkat selalu mempersyaratkan

\footnotetext{
* Corresponding author.

E-mail Addresses (I Made Mariawan), (Ni Ketut Rapi), (Putu Yasa),
} 
adanya kedit point terkait dengan publikasi ilmiah yang besarnya semakin meningkat dari satu jenjang ke jenjang berikutnya. Sebagai contoh, seorang guru yang akan naik pangkat dari IIIC ke IIID wajib melaksanakan kegiatan pengembangan diri dengan angka kredit 3 dan publikasi karya ilmiah atau karya inovatif dengan angka kredit 6. Dalam kenyataannya, peluang yang diberikan oleh pemerintah untuk peningkatan karir dan kesejahteraan guru, tidak selalu dapat diraih dengan mudah oleh sebagian besar guru-guru di Indonesia. Selain melalui kenaikan pangkat, upaya yang telah dilakukan pemerintah dalam meningkatkan profesionalisme dan kesejahteraan guru adalah melalui sertifikasi guru.

Penjabaran dari UU No. 20 tahun 2003 tentang sistem pendidikan nasional, mendasarkan pada profesionalisme guru, yaitu standar kompetensi yang harus dikuasai seorang pendidik (guru). Dijelaskan, standar kompetensi yang harus dimiliki guru mencakup empat jenis kompetensi yaitu: kompetensi pedagogik, kepribadian, profesional, dan sosial. Kompetensi pedagogik adalah kemampuan mengelola pembelajaran yang meliputi pemahaman peserta didik, perancangan dan pelaksanaan pembelajaran, evaluasi hasil belajar, dan pengembangan peserta didik untuk mengaktualisasikan berbagai potensi yang dimilikinya. Kompetensi kepribadian adalah kemampuan kepribadian yang mantap, stabil, dewasa, arif dan berwibawa, menjadi teladan peserta didik, dan berakhlak mulia. Kompetensi professional adalah kemampuan penguasaan materi pembelajaran secara luas dan mendalam, yang memungkinkannya membimbing peserta didik memenuhi standar kompetensi yang ditetapkan dalam standar nasional pendidikan. Kompetensi sosial adalah kemampuan pendidik sebagai bagian dari masyarakat untuk berkomunikasi dan bergaul secara efektif dengan peserta didik, sesama pendidik, tenaga kependidikan, orang tua/wali peserta didik, dan masyarakat sekitar (Dirjen Dikti, 2005). Persyaratan kompetensi guru tersebut dibuktikan dengan sertifikat pendidik yang diperoleh melalui sertifikasi.

Sertifikasi guru dalam jabatan tahun 2014 yang dilaksanakan di Rayon 21 Universitas Pendidikan Ganesha telah berlangsung. Pengalaman pengusul, sebagai anggota assessor sertifikasi guru dalam jabatan di Rayon 21 Universitas Pendidikan Ganesha, melihat bahwa pengetahuan, pemahaman, dan pengalaman para guru dalam melaksanakan penelitian khususnya penelitian tindakan kelas (PTK) dan menulis artikel ilmiah sangat kurang. Rata-rata skor yang mereka peroleh kurang dari 6,0.

Melihat kenyataan yang diuraikan di atas, tampaknya perlu dilakukan suatu kegiatan yang mampu meningkatkan pemahaman dan keterampilan para guru dalam mengembangkan profesionalismenya, khususnya dalam pengembangan diri dan pengembangan karya tulis ilmiah. Hal ini akan dilakukan melalui kegiatan pengabdian pada masyarakat (P2M) sebagai salah satu kegiatan Tri Dharma Perguruan Tinggi yang mutlak dilakukan oleh dosen. Kegiatan P2M ini akan dilakukan di Sekolah Dasar (SD) di Kebendesaan Mengesta melalui pelatihan dan pendampingan PTK. Khalayak yang menjadi sasaran kegiatan ini adalah para guru SD di Kebendesaan Mengesta, Penebel, Tabanan. Kegiatan ini berupa lanjutan dari kegiatan P2M sebelumnya yang sudah berhasil melatih para guru dalam membuat media pembelajaran inovatif bagi siswa SD di Kecamatan Penebel.

Kebendesaan Mengesta adalah salah satu kebendesaan yang terletak di Kecamatan Penebel. Lokasi Kecamatan Penebel Kabupaten Tabanan, sekitar $80 \mathrm{~km}$ dari kota Singaraja, dengan medan yang cukup berat. Sekolah Dasar (SD) yang ada di Kecamatan Penebel sebanyak 34 sekolah. Lokasi sekolah, sebagian besar terletak di daerah pedesaan sehingga kegiatan P2M di bidang pendidikan yang dilakukan oleh Universitas Pendidikan Ganesha sangat jarang sampai ke wilayah-wilayah tersebut. Lokasi-lokasi sekolah yang sebagian besar terletak pada daerah yang agak terpencil mengakibatkan para guru jarang terlibat dalam kegiatan-kegiatan ilmiah yang dilakukan oleh Perguruan Tinggi. Sebagai dampaknya pengetahuan dan pemahaman para guru di wilayah ini masih kurang terkait dengan PTK dan penulisan karya ilmiah ataupun inovasi-inovasi kegiatan pembelajaran lainnya. Informasi ini diperoleh dalam kegiatan P2M yang telah dilaksanakan pada tahun 2015 di Kecamatan Penebel, khususnya di Kebendesaan Mengesta (Mariawan, Parwati, \& Yasa, 2015).

Berdasarkan hasil wawancara yang dilakukan pada tanggal 30 Mei 2015 dengan beberapa guru SD, kepala SD yang ada di Mengesta, dan Kepala UPTD Kecamatan Penebel diperoleh informasi bahwa pengetahuan dan pemahaman para guru di daerah ini terkait dengan PTK sangat kurang sehingga mereka kesulitan dalam menulis karya tulis ilmiah terutama karya tulis ilmiah dari hasil penelitian. Sebagai dampaknya, mereka sangat sulit untuk bisa naik pangkat karena terganjal dengan adanya persyaratan penulisan karya tulis ilmiah. Di samping itu, masalah-masalah yang muncul dalam kegiatan pembelajaran, sering tidak mendapatkan penanganan yang tepat karena jarang/tidak diawali dengan melakukan refleksi terhadap penyebab munculnya masalah itu. Ketidaktepatan dalam menangani masalah-masalah dalam pembelajaran akan berdampak pada tidak optimalnya proses dan hasil belajar yang dicapai siswa.

Berdasarkan wawancara tersebut juga diperoleh informasi, kepala UPTD, para kepala sekolah dan guru-guru sangat mengharapkan kegiatan P2M seperti ini agar bisa dilakukan secara berkesinambungan karena menurut mereka para guru di daerah ini sangat memerlukan bantuan berupa pelatihan dan pendampingan PTK yang nantinya bisa dilanjutkan dengan kegiatan penulisan artikel hasil 
penelitian. Sekolah dasar yang ada di Kebendesaan Mengesta sebanyak tiga SD, meliputi: SD 1 Mengesta, SD 2 Mengesta, dan SD 3 Mengesta dengan keberadaan guru sebanyak 32 orang. Mempertimbangkan jumlah guru yang cukup banyak, dengan pemahaman yang masih kurang dalam PTK, maka dipandang perlu untuk mengadakan kegiatan P2M yang melibatkan para guru di daerah ini. Kegiatan P2M ini akan dilakukan melalui pelatihan dan pendampingan PTK, yaitu dimulai dari pelatihan penyusunan proposal dilanjutkan dengan pendampingan pelaksanaan PTK di kelas bagi guru-guru di tiga Sekolah Dasar di Kebendesaan Mengesta.

Kegiatan ini dimaksudkan untuk mengubah mindset para guru di sekolah tersebut agar mau melaksanakan pembelajaran secara lebih efektif dan inovatif. Di samping itu, agar para guru khususnya dalam mengajar mau melakukan inovasi-inovasi sebagai bagian dari tugas profesionalismenya. PTK yang dilaksanakan oleh para guru nantinya, diharapkan dapat memperbaiki kualitas proses dan hasil belajar siswa.

\section{Metode}

P2M ini dilaksanakan dalam bentuk pelatihan dan pendampingan pelaksanaan PTK, yang terdiri dari dua tahap yaitu: tahap pertama, pelatihan penyusunan proposal yang diikuti oleh semua guru dan kepala sekolah di tiga SD Kebendesaan Mengesta, dan tahap kedua, pendampingan secara intensif kepada 6 orang guru di masing-masing SD untuk melaksanakan PTK sesuai dengan proposal yang telah dihasilkan pada tahap pelatihan. Pelaksanaan masing-masing tahap diuraikan sebagai berikut. Tahap Pelatihan, langkah-langkah kegiatannya adalah sebagai berikut. a) Merencanakan waktu dan tempat pelatihan bekerja sama dengan Kepala UPTD Pendidikan Kecamatan Penebel. b) Pelatihan tentang penyusunan proposal PTK bagi guru-guru peserta P2M. c) Diskusi dan tanya jawab tentang PTK antara pelatih dengan peserta. Simulasi salah satu atau beberapa proposal yang telah dihasilkan. Tahap Pendampingan, langkah-langkah kegiatannya adalah sebagai berikut. 1) Pendampingan pelaksanaan PTK pada kelas masing-masing. 2) Refleksi pelaksanaan PTK di tempat guru bertugas. Evaluasi dilakukan terhadap kemampuan guru dalam menyusun proposal

PTK dan melaksanakan PTK di kelas masing-masing. Instrumen yang digunakan untuk menilai kualitas proposal adalah rubrik penilaian proposal PTK dan penilaian terhadap pelaksanaan PTK dilakukan menggunakan lembar observasi pelaksanaan pembelajaran dan penilaian terhadap kualitas laporan PTK yang dihasilkan guru menggunakan rubrik penilaian laporan PTK. Penilaian terhadap kualitas RPP dan kemampuan mengajar guru dilakukan menggunakan rubrik penskoran dengan skala Likert dengan rentangan skor 1 sampai 5.. Analisis data dilakukan secara deskriptif.

\section{Hasil Dan Pembahasan}

Hasil yang dicapai melalui kegiatan P2M ini dituangkan dalam bentuk hasil kegiatan pada setiap tahap pelaksanaan, sebagai berikut. Tahap Pelatihan, langkah-langkah kegiatannya adalah sebagai berikut. Merencanakan waktu dan tempat pelatihan bekerja sama dengan Kepala UPTD Pendidikan Kecamatan Penebel. Pelaksanaan tahap ini didahului dengan, tim pelaksana mengadakan pertemuan persiapan pelaksanaan dengan melibatkan LPM Undiksha dan Kepala UPTD. Kegiatan ini dilakukan pada bulan Juni 2016. Tim pelaksana memberikan pembekalan mengenai maksud, tujuan, rancangan mekanisme program P2M, dan beberapa hal teknis berkaitan dengan metode/teknik pelaksanaan. Sosialisasi program P2M pada tiga sekolah mitra (khalayak sasaran). Sosialisasi dilakukan pada bulan Juli 2016 dalam bentuk rapat koordinasi dengan mengundang semua guru pada sekolah mitra yaitu SD 1 Mengesta, SD 2 Mengesta, dan SD 3 Mengesta, Kepala Sekolah, dan Kepala UPTD Dinas Pendidikan Pemuda Dan Olah Raga Kecamatan Penebel, berkenaan dengan program yang dilaksanakan.

Kegiatan sosialisasi dilakukan oleh Tim Pelaksana didampingi oleh LPM Undiksha. Pelatihan tentang penyusunan proposal PTK bagi guru-guru peserta P2M. Berdasarkan hasil identifikasi, hasil analisis permasalahan yang ada, hasil analisis kebutuhan, dan hasil analisis potensi sekolah, selanjutnya disusun program pelatihan. Pelaksanaan pelatihan dilakukan selama 1 hari tatap muka, dengan mengundang 32 orang guru SD yang ada di Kebendesaan Mengesta. Pelaksanaan pelatihan didahului dengan pemberian materi tentang hakikat penelitian tindakan kelas (PTK), dilanjutkan dengan kegiatan diskusi dengan peserta, kemudian pelatihan penyusunan proposal PTK. Kegiatan pelatihan diakhiri dengan simulasi beberapa proposal yang berhasil disusun.

Melaksanakan evaluasi terhadap proposal yang dihasilkan dari kegiatan pelatihan. Hasil evaluasi adalah dipilihnya 2 proposal yang terbaik di masing-masing sekolah, pada tiga SD yang ada di Kebendesaan Mengesta sehingga total banyak guru yang dilibatkan dalam kegiatan pendampingan ada 6 orang. 
Keenam orang guru yang dipilih berdasarkan hasil pelatihan, selanjutnya mengimplementasikan pembelajaran sesuai dengan proposal yang dihasilkan. Pelaksanaan pembelajaran dilakukan dengan memberikan pendampingan oleh tim pelaksanan P2M. Masing-masing guru diberikan pendampingan sebanyak 2 kali pertemuan.

Kemampuan guru dalam melaksanakan PTK dalam pembelajaran di kelas, dinilai menggunakan alat penilaian kemampuan guru (APKG) yang diadopsi dari APKG sertifikasi guru rayon 21 Undiksha tahun 2013. Hasil evaluasi adalah rata-rata kemampuan mengajar guru dalam melaksanakan PTK berkualitas "sangat baik". Respon siswa terhadap pelaksanaan pembelajaran yang dilakukan guru ratarata berkualitas "sangat baik".

Kegiatan P2M yang dilaksanakan pada guru-guru SD di Kebendesaan Mengesa telah berlangsung dengan baik. Hal ini terlihat dari animo guru untuk mengikuti kegiatan pelatihan sangat tinggi, terbukti dengan kehadiran para guru untuk mengikuti kegiatan mencapai 100\%. Hal ini mengindikasikan bahwa para guru menyambut positif kegiatan yang telah dilakukan. Sesuai dengan harapan para sekolah, mereka sangat mengharapkan adanya kegitan-kegiatan yang sifatnya memberi penyegaran bagi para guru di daerah ini, baik terkait dengan pendalaman materi bidang studi ataupun terkait dengan metode mengajar, mengingat hampir 60\% dari para guru sudah berumur di atas 40 tahun.

Kepala sekolah, kepala UPTD, dan pengawas, menyambut antusias terkait pelaksanaan kegiatan P2M ini. Pengawas yang hadir, berharap agar dilakukan kegiatan secara berkesinambungan dan disarankan untuk melakukan kegiatan lanjutan dengan memilih topik yang lain. Pengawas dan kepala UPTD juga berharap agar ada pembinaan dari perguruan tinggi di daerah ini untuk meteri olimpiade.

Dalam kegiatan pelatihan, para guru sangat antusias dalam penyusunan proposal PTK. Hal ini karena mereka dapat merancang kegiatan pembelajaran yang secara langsung untuk memecahkan masalah yang dihadapi di kelas masing-masing. Di samping itu, dalam upaya kenaikan pangkat, para guru dituntut untuk mempunyai laporan hasil PTK. Banyak masukan yang diberikan, baik oleh para guru ataupun oleh tim pelaksana P2M terkait dengan pelaksanaan PTK. Masukan yang diberikan oleh tim pelaksana P2M lebih banyak terkait masalah yang dihadapi di kelas masing-masing dikaitkan dengan pemilihan model/strategi pembelajaran yang tepat.

Melalui kegiatan pendampingan, pelaksanaan PTK dapat berlangsung dengan baik. RPP yang disusun disesuaikan dengan kurikulum 2013, dengan menyusun RPP tematik. RPP yang disusun berkualitas baik. Kemampuan guru yang dinilai menggunakan APKG, berkualitas baik. Rata-rata siswa memberikan tanggapan yang positif terhadap pelaksanaan pembelajaran yang dilakukan guru.

Kendala-kendala yang dihadapi dalam pelaksanaan P2M ini adalah masalah waktu pelaksanaan sering terganggu dengan adanya hari-hari libur keagamaan dan kegiatan-kegiatan yang lain. Di samping itu masalah yang cukup mengganggu adalah keterlambatan pencairan dana, sehingga waktu pelaksanaan kegiatan menjadi mundur, tidak bisa berlangsung sesuai dengan rencana. Namun, semua kendala dan masalah yang muncul telah dicarikan solusinya, yaitu dengan melaksanakan kegiatan pelatihan pada hari sabtu dan dengan melibatkan teman sejawat dalam kegiatan pendampingan. Dengan demikian kegiatan P2M ini telah berlangsung dengan baik.

\section{Simpulan Dan Saran}

Hasil yang dicapai melalui kegiatan P2M ini adalah 6 orang guru yang dipilih pada masing-masing sekolah dengan hasil proposal terbaik dengan rata-rata skor adalah 4,1. Rata-rata kemampuan guru dalam melaksanakan PTK, berkualitas "sangat baik". RPP yang disusun guru, berkualitas "baik". Rata-rata respon siswa terhadap pelaksanaan pembelajaran yang dilakukan guru, berkualitas "sangat baik".

Berdasarkan hasil yang diperoleh dalam kegiatan P2M ini, maka para guru dalam melaksanakan kegiatan pembelajaran khususnya, agar melakukan kegiatan refleksi terlebih dahulu sehingga pelaksanaan pembelajaran dapat berlangsung secara efektif. Para guru SD agar senantiasa berupaya secara terus menerus mengembangkan kemampuan profesionalisme guru melalui kegiatan KKG, agar masalah-masalah yang dihadapi dalam pelaksanaan pembelajaran di kelas masing-masing dapat dicarikan solusinya secara bersama-sama.

\section{Daftar Pustaka}

Elliot, J. (1991). Action Research for Educational Change. Philadelphia: Open University Press.

Dunkin, Michael J. and Bruce J. Biddle. 1974. The Study of Teaching. USA: Holy, Rinehart and Winston, Inc.

Hopkins, David. 1993. A Teacher's Guide to Classroom Research. Philadephia: Open University Press. 
Kemmis, S. \& McTaggart, R. (1988). 3². The Action Research Planner. Victoria: Deakin University.

Parwati, N.N \& I W. Kertih. 2007. Penelitian Tindakan kelas. (Modul). Disampaikan pada Pendidikan dan Latihan Profesi Guru (PLPG) 2007. Singaraja: Undiksha.

McNiff, J. 1992. Action Research: Principles and Practice. London: Routledge, Co.

McTaggart, R.. 1993. Action Research: A Short Modern History. Victoria: Deakin University.

Martha E. Ruddel. D. Rosalind Hammond, and Ted W. Preeman. 1993. Theory and Research in Social Education. Vol. 4. Washington DC: NCSS.

Oja, S. N. \& Smulyan, L. 1989. Collaborative Action Research: A Developmental Appraisal. London: The Palmer Press.

Rochiati, Wiriatmadja 2005. Metode Penelitian Tindakan Kelas. PT. Remaja Kosdakarya: Bandung.

Santyasa, I.W. 1999. Konsep Dasar Penelitian Tindakan Kelas. Makalah. disajikan dalam pelatihan terakreditasi guru-guru Fisika SMA Se provinsi Bali 20Nopember s.d 3 Desember 1999. di Denpasar.

Sukamto. 1994. Panduan Penelitian Tindakan: Seri Metodologi Penelitian. Yogyakarta: Lembaga penelitian IKIP Yogyakarta.

Suwarsih, Madya, dkk. 1994. Panduan Penelitian Tindakan. Jogyakarta: Lembaga Penelitian IKIP Jogyakarta. 